\title{
Author Correction: Limited capacity of tree growth to mitigate the global greenhouse effect under predicted warming
}

\author{
Ulf Büntgen 1,2,3, Paul J. Krusic ${ }^{1,4}$, Alma Piermattei ${ }^{1}$, David A. Coomes ${ }^{5}$, Jan Esper ${ }^{6}$, Vladimir S. Myglan, \\ Alexander V. Kirdyanov ${ }^{1,8,9}$, J. Julio Camarero ${ }^{10}$, Alan Crivellaro ${ }^{1} \&$ Christian Körner $^{11}$
}

Correction to: Nature Communications https://doi.org/10.1038/s41467-019-10174-4, published online 15 May 2019.

The original HTML version of this Article was updated after publication to add links to the Source Data.

Published online: 17 June 2019

\begin{abstract}
(c) (i) Open Access This article is licensed under a Creative Commons Attribution 4.0 International License, which permits use, sharing, adaptation, distribution and reproduction in any medium or format, as long as you give appropriate credit to the original author(s) and the source, provide a link to the Creative Commons license, and indicate if changes were made. The images or other third party material in this article are included in the article's Creative Commons license, unless indicated otherwise in a credit line to the material. If material is not included in the article's Creative Commons license and your intended use is not permitted by statutory regulation or exceeds the permitted use, you will need to obtain permission directly from the copyright holder. To view a copy of this license, visit http://creativecommons.org/licenses/by/4.0/.
\end{abstract}

(C) The Author(s) 2019

\footnotetext{
${ }^{1}$ Department of Geography, University of Cambridge, Cambridge CB2 3EN, UK. ${ }^{2}$ Swiss Federal Research Institute (WSL), 8903 Birmensdorf, Switzerland. ${ }^{3}$ Global Change Research Centre and Masaryk University, 61300 Brno, Czech Republic. ${ }^{4}$ Department of Physical Geography, Stockholm University, 10691 Stockholm, Sweden. ${ }^{5}$ Department of Plant Sciences, University of Cambridge, Cambridge CB2 3EA, UK. ${ }^{6}$ Departmemt of Geography, Johannes Gutenberg University, 55099 Mainz, Germany. ${ }^{7}$ Institute of Humanities, Siberian Federal University, 660041 Krasnoyarsk, Russia. ${ }^{8}$ Sukachev Institute of Forest SB RAS, 660036 Krasnoyarsk, Russia. ${ }^{9}$ Institute of Ecology and Geography, Siberian Federal University, 660041 Krasnoyarsk, Russia. ${ }^{10}$ Instituto Pirenaico de Ecología (IPE-CSIC), 50059 Zaragoza, Spain. ${ }^{11}$ Institute of Botany, University of Basel, 4056 Basel, Switzerland. Correspondence and requests for materials should be addressed to U.B. (email: ulf.buentgen@geog.cam.ac.uk)
} 